\section{Д.О. Степанський,} Г.М. Кременчуцький, І.П. Кошова

\section{ДОКЛІНІЧНЕ ВИВЧЕННЯ ВЛАСТИВОСТЕЙ АУТОСИМБІОНТІВ ЛЮДИНИ А. VIRIDANS}

Д3 «Дніпропетровська медична академія МОЗ України»

кафедра мікробіологї, вірусології, імунологї̈ та епідеміології

(зав. - к. мед. н. Д.О. Степанський)

пл. Соборна, 4, Дніпропетровськ, 49000, Украӥна

$S E$ «Dnipropetrovsk medical academy of Health Ministry of Ukraine»

Department of Microbiology, virology, immunology and epidemiology

Soborna Sq., 4, Dnipropetrovsk, 49000, Ukraine

e-mail: sd801@yandex.ru

Ключові слова: пробіотики, доклінічне вивчення, аерококи

Key words: probiotics, preclinical study, aerococcus

Реферат. Доклиническое изучение свойств аутосимбионтов человека. А. Viridans. Степанский Д.А., Кременчуцкий Г.Н., Кошевая И.П. В работе представлены данные доклинического изучения свойств аутосимбионтов A. viridans. Штаммы бактерий рода Аегососсиs проверень по морфологическим, культуральным, тинкториальным и биохимическим свойствам на отсутствие контаминации, была изучена чувствительность к антибиотикам, активность глутатионпероксидазы, супероксидного радикала, супероксидазы, СОД. Проведено определение острой токсичности и безвредности испытуемых штаммов. Аэрококки хорошо накапливают массу на стандартных питательных средах, морфология, тинкториальные и биохимические свойства соответствуют стандартам. Все показатели активности глутатионпероксидазы, супероксидного радикала, супероксидазы, СОД, количество белка также соответствуют стандартам. Антагонистическая активность исследуемых итаммов аэрококков была изучена методом отсроченного антагонизма к тесткультурам. Данные свидетельствуют о высокой антагонистической активности итаммов аэрококков к условно-патогенным микроорганизмам. $B$ ходе определения острой токсичности аэрококков в период наблюдения не было выявлено отеков и некроза тканей в местах инъекций аэрококков, гибели мышей не отмечено. Показана полная безвредность при введении белым мышам per os микробной взвеси аэрококков.

\begin{abstract}
Preclinical study of the properties of human autosymbionts A. Viridans. Stepanskyi D.O., Kremenchutskyi G.M., Koshova I.P. The paper presents data of preclinical study of autocamiones A. viridans properties. Acute toxicity and harmlessness of strains was tested. Strains of bacteria of Aerococcus genus were checked for absence of contamination by morphological, cultural, biochemical and tinctorial properties. Aerococci accumulate weight well on standard nutrient media, morphology, tinctorial and biochemical properties meet the standards. All indicators of activity of glutathione peroxidase, superoxide radical, superoxide, SOD, protein content comply with the standards. Antagonistic activity of the studied strains of aurococcus was investigated by the method of deferred antagonism to test cultures. Data show a high antagonistic activity of aurococcus strains to conditionally pathogenic microorganisms. During determination of acute toxicity of aurococcus in the observation period, edema and tissue necrosis at the injection site of aurococcus, death of mice was not marked were not revealed. A complete harmlessness of microbial suspension of aurococcus when administered to white mice per os was revealed.
\end{abstract}

Нормальна мікрофлора організму людини являє собою сукупність різних біоценозів, що займають численні екологічні ніші на шкірі і слизових оболонках всіх порожнин, сполучених із зовнішнім середовищем $[6,8]$. Зменшення кількості нормальної кишкової мікрофлори призводить до ослаблення конкуренції з патогенами за рецептори слизової оболонки кишечнику, знижується місцевий імунітет продукція лізоциму, імуноглобуліну А [2].

Сформована ситуація вимагає пошуку нових антибактеріальних засобів і підходів до лікування. Одним 3 найбільш обговорюваних в останні роки підходів до профілактики та лікування кишкових інфекцій $є$ застосування пробіотиків $[2,5,6]$.

Багатьма дослідниками встановлено важливу роль нормальної мікрофлори організму людини у підтримці його фізіологічного стану, забезпеченні гомеостазу і життєдіяльності [7].

Однак $є$ невелика кількість фундаментальних досліджень, присвячених Aerococcus, Acetovibrio, Butyrivibrio, Centipeda, Eutactarrium, Leptotrichia, Ruminobacteria, Solenomonas, Succinivibrio. Aerococcus viridans мають цілий ряд корисних властивостей, вироблених у процесі динамічної взаємодії як з макроорганізмом, так i 3 мікробіоасоціантами [2]. Наприклад, виявлена 
здатність аерококів окисляти молочну кислоту призводить до зниження рівня гіпоксії в кишечнику; виділення пероксиду водню, який розщеплюється каталазою епітелію кишечнику і також призводить до оксигенації тканин $[1,5]$.

Глутатіонредуктазна активність, утворення кон'югатів глутатіону 3 ксенобіотиками та інші корисні властивості становлять інтерес для подальшого вивчення їх впливу на гомеостаз макроорганізму [4].

У 9-му виданні Bergey's Manual of Determinative Bacteriology [7] аерококи представлені в групі № 17 (грампозитивні коки) у вигляді окремого роду Aerococcus, відзначеного тільки одним типовим видом Aerococcus viridans. Цим бактеріям у визначнику мікроорганізмів дана така морфологічна характеристика: клітини сферичні, 1,0-2,0 мкм у діаметрі, що розташовуються тетрадами при рості на підходящих рідких середовищах. Грампозитивні, нерухливі, факультативні анаероби, однак значно краще ростуть при нормальному парціальному тиску кисню в живильних середовищах. $Є$ мікроаерофілами, не розмножуються в анаеробних умовах. У процесі аеробного росту продукують $\mathrm{H}_{2} \mathrm{O}_{2}$, i маркером $€$ позеленіння кров'яного агару, хемоорганотрофи з окисним метаболізмом. Каталазонегативні, желатину не розщеплюють, нітрати не редукують. Оптимум росту $36^{\circ} \mathrm{C}$, припиняють ріст при $45^{\circ} \mathrm{C}$. Ростуть при $\mathrm{pH} 9,6$ в $10 \% \mathrm{NaCl}$ і $40 \%$ жовчі.

Згідно 3 даними, отриманими С.А. Риженко i Г.М.Кременчуцьким, аерококи продукують у зовнішнє середовище пептид широкого спектру дії - аероцин, що проявляє високі антагоністичні діï відносно різних видів кандид [4]. Сучасне використання аерококів у вигляді препарату «Абактерин» 3 йодидом калія i етонієм $\epsilon$ ефективним при урогенітальних кандидозах, оскільки забезпечує направлене пошкодження мембран кандид [8].

Той же ефект досягається в результаті вживання аерококів як засобу профілактики кандидозів, що виникають унаслідок пригнічення імунітету при ВІЛ [9].

Проведена серія експериментів in vitro 3 вивчення спектру антагоністичної дії A. viridans 167 переконливо й наочно продемонстрували високу інгібуючу активність бактерій цього роду відносно збудників госпітальних інфекцій і мікроорганізмів, що беруть участь у формуванні патологічного мікробіоценозу кишечнику людини [9].

Метою дослідження було доклінічне вивчення властивостей аутосимбіонтів A.viridans, які представляють собою суспензію живих бактерій роду Aerococcus у стерильному фосфатному буфері pH 7,2-7,4 з концентрацією 200 млн/мл (1 ОД). Діюча речовина аутосимбіонтного препарату (АСП) - живі штами аерококів (Aerococcus viridans, виділені з організму людини).

\section{МАТЕРІАЛИ ТА МЕТОДИ ДОСЛІДЖЕНЬ}

Для вивчення специфічної активності аерококів були використані такі штами Aerococcus viridans: № 23, № 131, № 165. № 23 - який виділений 3 мигдалин здорової людини. № 131 калу здорової людини. № 165 - шкіри здорової людини.

Вивчення морфології та тинкторіальних властивостей проводили за допомогою мікроскопії (препарати живих та забарвлених мікроорганізмів).

Вивчення культуральних властивостей визначали за характерним ростом на щільних, рідких та напіврідких селективних середовищах.

Вивчення фізіолого-біохімічних властивостей проводили за допомогою зареєстрованих діагностичних тест-систем для ідентифікації бактерій компанії "ERBA-Lachema Diagnostika". Також визначали такі показники: цукролітичні ферменти, протеолітичні властивості (каталазну, лецитіназну, плазмокоагулазну, фібринолітичну активність), лізоцимну, гіалуронідазну та гемолітичну активність.

Чутливість до антибіотиків визначалася методом дифузії в агар з використанням дисків [3]. Антагоністична дія аерококів по відношенню до тест - культур мікроорганізмів вивчалася 3 використанням методики відстроченого антагонізму.

Активність глутатіонпероксидази визначалася за методом [13]. Білок визначався за методом [11]. Супероксидний радикал визначався за методом [12]. Активність супероксидази визначалася за методом [3]. Активність СОД виражали в мкмоль/мін. мг білка.

Досліди адгезивної активності проводили за методом Брилис В.И. [1].

Визначення стійкості штаму до дії шлункового соку. 3 метою вивчення стійкості досліджуваних штамів до дії шлункового соку 1,5 мл добової культури центрифугували при 3 тис. об/хв протягом 5 хв, відмивали у фізіологічному розчині і знову центрифугували. Осад ресуспендували в 1,5 мл шлункового соку (рН 2.0) (ЗАТ "Біофарма", Україна) та інкубували 2 год. при температурі $37^{\circ} \mathrm{C}$. Ступінь виживання бактерій визначали на MRS-агарі врахуванням кількості КУО через 48 год. інкубації при $37{ }^{\circ} \mathrm{C}[7,14]$. У 
контролі замість шлункового соку використовували фізіологічний розчин того самого об'єму.

Визначення гострої токсичності проводили на мишах лінії СВА масою тіла від 10 до 14 г. Культуру 2-го пасажу, вирощену на щільному живильному середовищі, змивали 0,9\% розчином натрію хлориду. В отриманій суспензії визначали концентрацію мікробних клітин по оптичному стандарту мутності. 3 отриманої суспензії робили ряд п'ятикратних розведень. Отриману суспензію різної концентрації $\left(10^{5}\right.$, $10^{6}, 10^{7}, 10^{8}, 10^{9}$ дози) мікробів вводили різними способами: внутрішньочеревно, внутрішньом'язово, підшкірно. Доза вводилась в обсязі 0,5 мл. Термін спостереження за тваринами - 7-14 діб. Після закінчення терміну спостереження розраховували LD50.

Визначення нешкідливості випробовуваних штамів проводили на 5 безпородних білих мишах масою $(15 \pm 1)$ г. Суспензію штамів 2-го або 3-го пасажу в концентрації $10^{8}$ мікробних клітин вводили в обсязі 0,5 мл перорально. Спостереження за мишами здійснювали протягом 5 діб.

Для статистичного аналізу використовували пакет прикладних програм Statistica v6.1®. Кількісні ознаки представлені у вигляді середнього значення та його стандартної похибки
$(\mathrm{M} \pm \mathrm{m})$. Для порівняння середніх величин застосовували критерій Стьюдента (t), відносних величин - критерій Хi-квадрат Пірсона $\left(\chi^{2}\right)$. Статистично значущими вважали відмінності при $\mathrm{p} \leq 0,05$.

\section{РЕЗУЛЬТАТИ ТА ЇХ ОБГОВОРЕННЯ}

Досліджувані штами бактерій роду Aerococcus перевірені за морфологічними, культуральними, тинкторіальними й біохімічними властивостями на відсутність контамінації (табл. 1-3). Визначення проводили відповідно до ФС «Виробничі штами i штами для контролю» i «Безпека пробіотиків для медичного застосування в тестах in vivo». 3 даних, наведених у таблицях 1 та 2, видно, що аерококи добре нарощують масу на стандартних поживних середовищах, морфологія, тинкторіальні та біохімічні властивості відповідають стандартам.

Методом серійних розведень була вивчена чутливість до антибіотиків, дані представлені в таблиці 2.

Активність глутатіонпероксидази, супероксидного радикалу, супероксидази, СОД, кількість білка представлені в таблиці 3. Всі показники активності відповідають стандартам.

\section{Морфологія клітин та характер росту культур аерококів}

\begin{tabular}{|c|c|c|c|}
\hline \multirow{2}{*}{ Морфологія } & \multicolumn{3}{|c|}{ Після зберігання аерококів } \\
\hline & Aerococcus viridans №23 & Aerococcus viridans №131 & Aerococcus viridans № 165 \\
\hline $\begin{array}{l}\text { При рості на м'ясо- } \\
\text { пептоному агарі (МПА) }\end{array}$ & $\begin{array}{c}\text { розташовуються тетрадами і } \\
\text { скупченнями неправильної } \\
\text { форми, коки грампозитивні } \\
\text { морфологія } \\
\text { та ж }\end{array}$ & $\begin{array}{c}\text { розташовуються тетрадами і } \\
\text { скупченнями } \\
\text { неправильної форми, коки } \\
\text { грампозитивні } \\
\text { морфологія } \\
\text { та ж }\end{array}$ & $\begin{array}{c}\text { розташовуються тетрадами і } \\
\text { скупченнями } \\
\text { неправильної форми, коки } \\
\text { грампозитивні } \\
\text { морфологія } \\
\text { та ж }\end{array}$ \\
\hline $\begin{array}{l}\text { Характер росту на: } \\
\text { МПА }\end{array}$ & $\begin{array}{c}\text { ріст гарний, колонії (1-2 мм у } \\
\text { діаметрі) з рівними краями, } \\
\text { опуклі, що не зливаються }\end{array}$ & $\begin{array}{l}\text { ріст гарний, колонії (1-2 мм у } \\
\text { діаметрі) з рівними краями, } \\
\text { опуклі, що не зливаються }\end{array}$ & $\begin{array}{c}\text { ріст гарний, колонії (1-2 мм у } \\
\text { діаметрі) з рівними краями, } \\
\text { опуклі, що не зливаються }\end{array}$ \\
\hline $\begin{array}{l}\text { МПА }+\mathbf{1 0 \%} \text { кінської } \\
\text { сироватки }\end{array}$ & $\begin{array}{c}\text { ріст бідний. Дрібні точечні } \\
\text { колонії }\end{array}$ & $\begin{array}{c}\text { ріст бідний. } \\
\text { Дрібні точечні колонії }\end{array}$ & $\begin{array}{c}\text { ріст бідний. } \\
\text { Дрібні точечні колонії }\end{array}$ \\
\hline МПБ & $\begin{array}{c}\text { ріст гарний у вигляді } \\
\text { пристінного і придонного осаду }\end{array}$ & $\begin{array}{c}\text { ріст гарний у вигляді } \\
\text { пристінного і придонного } \\
\text { осаду }\end{array}$ & $\begin{array}{c}\text { ріст гарний у вигляді } \\
\text { пристінного і придонного } \\
\text { осаду }\end{array}$ \\
\hline $\begin{array}{l}\text { МПА } 3 \text { 0,05\% } \\
\text { селенистокислого } \\
\text { натрію }\end{array}$ & $\begin{array}{c}\text { ріст гарний, великі (2-3 мм у } \\
\text { діаметрі) колонії червоного } \\
\text { кольору }\end{array}$ & $\begin{array}{c}\text { ріст гарний, великі (2-3 мм у } \\
\text { діаметрі) колонії червоного } \\
\text { кольору }\end{array}$ & $\begin{array}{c}\text { ріст гарний, великі (2-3 мм у } \\
\text { діаметрі) колонії червоного } \\
\text { кольору }\end{array}$ \\
\hline
\end{tabular}


Таблиця 2

\section{Властивості культур аерококів}

\begin{tabular}{|c|c|c|c|}
\hline \multirow{2}{*}{ Властивості культур } & \multicolumn{3}{|c|}{ Після зберігання аерококів } \\
\hline & A. viridans № 23 & A. viridans № 131 & A. viridans № 165 \\
\hline при рН 9,6 & Pict & Pict & Pict \\
\hline при $45^{\circ} \mathrm{C}$ & Ріст відсутній & Ріст відсутній & Ріст відсутній \\
\hline \multicolumn{4}{|c|}{ Антиб̈іотики МІК (мкг/мл) } \\
\hline Пеніцилін & 0,12 & 0,12 & 0,12 \\
\hline Оксацилін & 0,12 & 0,12 & 0,12 \\
\hline Метицилін & 0,12 & 0,12 & 0,12 \\
\hline Стрептоміцин & 3,84 & 3,84 & 3,84 \\
\hline Лізоцим & 1,92 & 1,92 & 1,92 \\
\hline Бікліноциклін & 0,12 & 0,12 & 0,12 \\
\hline Карбеніцилін & 3,84 & 3,84 & 3,84 \\
\hline Грамурин & 1000 & 1000 & 1000 \\
\hline Дюксидин & 30,72 & 30,72 & 30,72 \\
\hline Невіграмон & 750 & 750 & 750 \\
\hline Димексид & 500,0 & 500,0 & 500,0 \\
\hline Хіноксидин & 1000 & 1000 & 1000 \\
\hline Аскорбінова кислота & 4000 & 4000 & 4000 \\
\hline Борна кислота & 500,0 & 500,0 & 500,0 \\
\hline Хлорамін & 500,0 & 500,0 & 500,0 \\
\hline Желатину & не розріджус & не розріджус & не розріджує \\
\hline \multicolumn{4}{|l|}{ Гідроліз: } \\
\hline Крохмалю & Не гідролізус & Не гідролізує & Не гідролізус \\
\hline
\end{tabular}

\begin{tabular}{lccc} 
& утилізація вуглеводів & + & \\
\hline Арабіноза & + & + & - \\
Рамноза & - & - & + \\
Інозит & + & + & + \\
Ксилоза & + & - & - \\
Сорбіт & - & + & + \\
Дульцит & + & + & + \\
Глюкоза & + & - & - \\
Лактоза & - & + & + \\
Мальтоза & + & + & + \\
Манніт & + & + & + \\
Сахароза & + & - & - \\
Лецитиназна активність & - & - & - \\
Плазмокоагулазна активність & - & - & + \\
Гемолітична активність & + & - & - \\
Фібринолітична активність & - & + &
\end{tabular}


Біологічна активність штамів аерококів $(\mathrm{M} \pm \mathrm{m})$

\begin{tabular}{|c|c|c|c|c|}
\hline \multirow[b]{2}{*}{ Штами } & \multicolumn{4}{|c|}{ Біологічна активність штамів аерококів } \\
\hline & $\begin{array}{c}\text { питома активність } \\
\text { супероксиддисмутази } \\
\text { ОД на } 1 \text { мг білка } \\
\text { за } 1 \text { хв }\end{array}$ & $\begin{array}{c}\text { питома активність GSH- } \\
\text { пероксидази ОД на } 1 \text { мг } \\
\text { білка за } 1 \text { хв }\end{array}$ & $\begin{array}{c}\text { активність ЛДГ OD } \\
\text { на } 1 \text { мг білка }\end{array}$ & $\begin{array}{c}\text { накопичення } \\
\text { пероксиду водню в } \\
\text { бульоні (мМ) }\end{array}$ \\
\hline № 23 & $12,1 \pm 0,9$ & $5,6 \pm 0,26$ & $1112 \pm 87$ & $20,2 \pm 0,08$ \\
\hline № 131 & $13,3 \pm 0,7$ & $5,1 \pm 0,11$ & $1071 \pm 74$ & $18,0 \pm 0,04$ \\
\hline № 165 & $11,9 \pm 0,4$ & $4,9 \pm 0,14$ & $1094 \pm 71$ & $23,3 \pm 0,06$ \\
\hline
\end{tabular}

Методом відстроченого антагонізму була вивчена чутливість тест-штамів: Proteus vulgaris, 401 Pseudomonas aeruginosa 1, Candida albicans 690, Escherichia coli 374, Staphylococcus aureus 209-p, Staphylococcus epidermidis ATCC 14990, Klebsiella ozaenae 390 та Citrobacter freundii Be
113/66. Дані, наведені в таблиці 4, свідчать про високу антагоністичну активність штамів аерококів до умовно-патогенних тест-штамів мікроорганізмів, зокрема до Staphylococcus epidermidis, Staphylococcus aureus Escherichia coli.

Таблиия 4

Антагоністична активність штамів аерококів до різних штамів тестових культур

\begin{tabular}{l|c|c|c}
\hline \multicolumn{1}{c|}{ Штами тест-культур } & \multicolumn{2}{c}{ Зона затримки росту (мм) $\mathrm{M} \pm \mathrm{m}, \mathrm{n}=10$} \\
\cline { 2 - 4 } & № 23 & № 131 & $12 \pm 1$ \\
\hline Proteus vulgaris 401 & $11 \pm 2$ & $12 \pm 4$ & $11 \pm 3$ \\
Pseudomonas aeruginosa 1 & $10 \pm 1$ & $9 \pm 2$ & $12 \pm 1$ \\
Candida albicans 690 & $11 \pm 2$ & $12 \pm 2$ & $16 \pm 1$ \\
Escherichia coli 374 & $15 \pm 4$ & $14 \pm 2$ & $13 \pm 1$ \\
Staphylococcus aureus 209-p & $16 \pm 2$ & $15 \pm 2$ & $16 \pm 3$ \\
Staphylococcus epidermidis ATCC 14990 & $17 \pm 3$ & $18 \pm 2$ & $11 \pm 2$ \\
Klebsiella ozaenae 390 & $13 \pm 1$ & $11 \pm 1$ & $14 \pm 3$ \\
Citrobacter freundii Be 113/66 & $12 \pm 2$ & $13 \pm 3$ & \\
\hline
\end{tabular}

У ході встановлення гострої токсичності аерококів за клінічним станом білих мишей усіх груп проводили постійний нагляд протягом перших шести годин, потім через кожні три години, протягом першої доби досліду. При цьому фіксували: початок і динаміку розвитку клінічних проявів отруєння, час загибелі дослідних тварин або відновлення прикмет поліпшення їх фізіологічного стану.

У наступні 14 діб досліду, щодоби три рази проводили визначення клінічного стану лабораторних тварин всіх груп. За весь час спосте- реження не було жодного випадку загибелі тварин, крім короткочасного зниження рухової активності в перші 3-4 години спостережень. У період спостереження не було виявлено набряків i некрозу тканин у місцях ін'єкцій аерококів. Надалі клінічний стан тварин дослідних i контрольної груп не відрізнявся (табл. 5).

Під час експерименту вивчення нешкідливості штамів аерококів показана повна нешкідливість: при введенні білим мишам per os мікробної суспензії аерококів у кількості $0,5 \times 10^{8}$ КУО на тварину загибелі мишей не відзначено. 
Вивчення гострої токсичності аерококів

\begin{tabular}{|c|c|c|c|c|c|}
\hline \multirow{3}{*}{ Метод введення } & \multicolumn{5}{|c|}{ Дози } \\
\hline & $10^{5}$ & $10^{6}$ & $10^{7}$ & $10^{8}$ & $10^{9}$ \\
\hline & \multicolumn{5}{|c|}{ Кількість мишей, які вижили } \\
\hline Внутрішньочеревно & 10 & 10 & 10 & 10 & 10 \\
\hline Внутрішньом'язово & 10 & 10 & 10 & 10 & 10 \\
\hline Підшкірно & 10 & 10 & 10 & 10 & 10 \\
\hline Контроль & 10 & 10 & 10 & 10 & 10 \\
\hline
\end{tabular}

Примітка: $\mathrm{n}=10$.

\section{ВИСНОВКИ}

1. Штами бактерій роду Aerococcus перевірені за морфологічними, культуральними, тинкторіальними і біохімічними властивостями на відсутність контамінації. 3 наведених даних видно, що аерококи добре нарощують масу на стандартних поживних середовищах, морфологія, тинкторіальні та біохімічні властивості відповідають стандартам.

2. Всі показники активності глутатіонпероксидази, супероксидного радикалу, супероксидази, СОД, кількість білка відповідають стандартам.

3. Антагоністична активність досліджуваних штамів аерококів була вивчена методом відстроченого антагонізму до тест-штамів. Дані свідчать про високу антагоністичну активність штамів аерококів до умовно-патогенних тестштамів мікроорганізмів, зокрема до Staphylococcus epidermidis, Staphylococcus aureus, Escherichia coli.

4. У ході встановлення гострої токсичності аерококів у період спостереження не було виявлено набряків і некрозу тканин у місцях ін'єкцій аерококів, загибелі мишей не відзначено.

5. Показана повна нешкідливість: при введенні білим мишам per os мікробної суспензії аерококів у кількості $0,5 \times 108$ КУО на тварину загибелі мишей не виявлено.

\section{СПИСОК ЛІТЕРАТУРИ}

1. Методика изучения адгезивного процесса микроорганизмов / В.И. Брилис, Т.А. Брилене, Х.Б. Ленцнер, А.А. Ленцнер // Лаб. дело. - 1986. - № 4. C. 210-212.

2. Коррекция дисбиотических нарушений при заболеваниях желудочно-кишечного тракта и печени биологически активными добавками с пробиотическим действием / Н.В. Соловьева, С.Н. Лейхтер, Т.А. Бажукова [и др.] // Обзоры по клинич. фармакологии и лекарственной терапии. - 2013. - № 8. C. $48-57$.

3. Костюк В.А. Простой и чувствительный метод определения активности супероксиддисмутазы, основанный на реакции окисления кверцетина / В.А. Костюк, А.И. Потапович, Ж.В. Ковалева // Вопросы мед. химии. - 1990. - № 2. - С. 88-91.

4. Кременчуцкий Г.Н. Роль микроэкологии организма человека и принципы ее коррекции / Г.Н. Кременчуцкий, С.А. Рыженко, С.И. Вальчук. - Днепропетровск: Пороги, 2003. - С. 58-59.

5. Моин В.И. Простой и чувствительный метод определения глутатионпероксидазы в эритроцитах / В.И. Моин // Лаб. дело. - 1986. - № 12. - С. 724-727.
6. Об унификации микробиологических методов исследования, применяемых в клинико-диагностических лабораториях лечебно-профилактических учреждений: Приказ№ 535 МЗ СССР от 22.04.1985. Москва, 1985. - 56 с.

7. Определитель бактерий Берджи. В 2 т. / под ред. Хулта Дж., Крига Н., Снита П. [и др.] [пер. с англ. под ред. Заварзина Г.А.]. - Москва: Мир, 2001.

8. Риженко C.А. Вплив живої культури Aerococcusviridans на фактори імунологічної реактивності організму людини invitro / C.A. Риженко, C.I. Вальчук // Одес. мед. журнал. - 2003. - № 5 (79). - С.108-111.

9. Рыженко С.А. Влияние А-бактерина на гомеостаз организма человека при различных патологических состояниях // Сб. материалов междунар. науч.-практ. конф. памяти Г.И. Гончаровой «Пробиотические микроорганизмы - современное состояние вопроса и перспективы использования» / под ред. В.А. Алешкина. - Москва, 2002. - С. 41-42.

10. Clinical efficacy of probiotics: review of the evidence with focus on children / S. Michail, F. Sylvester, G. Fuchs [et al. ] // J. Pediatr. Gastroenterol. Nutr. - 2006. Vol. 43, N4. - P. $550-557$. 
11. Lowry O.H. Protein measurement with the folin phenol reagent / O.H. Lowry // Biol. Chem. - 1951. Vol. 193, N 1. - P. 265-275.

12. Glutathione peroxidase, superoxide dismutase, and catalase inactivation by peroxides and oxygen derived free radicals / E.Pigeolet, P.Corbisier, A.Houbion [et al. ] // Mech Ageing Dev. - 1990.Vol.51, N 3. - P. 283-297.
13. Steinhoff U. Who controls the crowd? New findings and old questions about the intestinal microflora / U. Steinhoff // Immunol. Letters. - 2005. - Vol. 99, Issue 1. - P. 12-16.

14. Yazid W.A. Survival of bifidobacteria in simulated gastric $\mathrm{pH}$ and growth in the presence of bile / W.A.Yazid, M. Shuhaimi, M. Ghazali // Asia J. Mol. Biol. Biotechnol. - 1999. - Vol. 7, N 2. - P. 185-188.

\section{REFERENCES}

1. Brilis VI, Brilene TA, Lentsner $\mathrm{KhB}$, Lentsner AA. [Methods of studying the adhesive process of microorganisms]. Lab. Delo. 1986;4:210-2. Russian.

2. Solov'eva NV, Leykhter SN, Bazhukova TA. [Correction of dysbiotic disorders in diseases of the gastrointestinal tract and liver with dietary supplements with a probiotic effect]. Obzory po klinicheskoy farmakologii i lekarstvennoy terapii. 2013;8:48-57. Russian.

3. Kostyuk VA, Potapovich AI, Kovaleva ZhV. [A simple and sensitive method for determining the activity of superoxide dismutase, based on the reaction of oxidation of quercetin]. Vopr. med. khimii. 1990;2:88-91. Russian.

4. Kremenchutskiy GN, Ryzhenko SA, Val'chuk SI. [Role of Microbiology of the human body and the principles of correction]. 2003;58-59. Russian.

5. Moin VI. [A simple and sensitive method for the determination of glutathione peroxidase in erythrocytes]. Lab. Delo. 1986;12:724-7. Russian.

6. On the unification of microbiological research methods used in clinical diagnostic laboratories of medical institutions. Prikaz№ 535 MZ SSSR ot 22.04.1985. M., 1985;56. Russian.

7. The determinant of bacteria Burgi: In 2 volumes (pod red. Khulta Dzh., Kriga N., Snita P. i dr.; per. s angl. pod red. Zavarzina G.A.). Izdatel'stvo: Mir; 2001. Russian.
8. Ryzhenko SA, Val'chuk SI. [The impact of living culture Aerococcus Viridans the factors immunological reactivity of human invitro]. Odes. med. zhurnal. 2003;5(79):108-11. Ukrainian.

9. Ryzhenko SA, Aleshkin VA. [Effect of A-bacterinum homeostasis in human organism at different pathological states]. Sb. materialov mezhdunar. nauch.-prakt. konf. pamyati G.I. Goncharovoy «Probioticheskie mikroorganizmy - sovremennoe sostoyanie voprosa i perspektivy ispol'zovaniya». 2002;41-42. Russian.

10. Michail S, Sylvester F, Fuchs G, Issenman R. Clinical efficacy of probiotics: review of the evidence with focus on children. J. Pediatr. Gastroenterol. Nutr. 2006;43(4):550-7.

11. Lowry OH. Lowry O.H. Protein measurement with the folin phenol reagent. Biol. Chem. 1951;193(1):265-75.

12. Pigeolet E, Corbisier P, Houbion A, Lambert D. Glutathione peroxidase, superoxide dismutase, and catalase inactivation by peroxides and oxygen derived free radicals. Mech Ageing Dev. 1990;51(3):283-97.

13. Steinhoff U. Who controls the crowd? New findings and old questions about the intestinal microflora. Immunology Letters. 2005;99(1):12-16.

14. Yazid WA, Shuhaimi M, Ghazali M. Survival of bifidobacteria in simulated gastric $\mathrm{pH}$ and growth in the presence of bile. Asia J. Mol. Biol. Biotechnol. 1999;7(2):185-8.

Стаття надійшла до редакції 05.04 .2016 